\title{
STUDY OF PARMELIA PERLATA FOR ITS POTENTIAL AS ANTI-INFLAMMATORY AND ANTIARTHRITIC AGENT USING IN VITRO MODEL
}

\author{
YOGESH DIWAKAR, CHITRA V*, EVELYN SHARON S
}

Department of Pharmacology, SRM College of Pharmacy, SRM IST, Kattankulathur, Tamil Nadu, India. Email: velchitram74@gmail.com Received: 16 July 2018, Revised and Accepted: 30 August 2018

ABSTRACT

Objective: The objective of this study was to evaluate the anti-inflammatory and antiarthritic potential of Parmelia perlata.

Methods: The relative study is based on in vitro anti-inflammatory and antiarthritic activity using hydroalcoholic extract of $P$. perlata (HAEPP). The preliminary phytochemical tests showed the presence of various phytochemical compounds such as alkaloids, flavonoids, and glycosides since the lichen species of P. perlata has the folklore claim of anti-inflammatory activity, thus it was studied by human red blood cells membrane stabilization method, and arthritic activity was carried using protein denaturation method using diclofenac as a standard.

Results: The results showed eminent anti-inflammatory and antiarthritic activity in a dose-dependent manner. The membrane stabilization showed the maximum effect at $78.54 \%$ at the concentration of $1000 \mu \mathrm{g} /$, and the protein denaturation was also found maximum at $1000 \mu \mathrm{g} / \mathrm{ml}$ concentration at $79.43 \%$. Thus, our research states the potent anti-inflammatory activity and antiarthritic effect in P. perlata.

Conclusion: The HEAPP has a potent anti-inflammatory activity and antiarthritic activity. A further study has to be conducted to establish the pharmacological evidence behind the compound and the mechanism of action of the HAEPP on the inhibition of the inflammation process.

Keywords: Parmelia perlata, Anti-inflammatory activity, Human red blood cells membrane stabilization, Antiarthritic activity, Protein denaturation.

(C) 2019 The Authors. Published by Innovare Academic Sciences Pvt Ltd. This is an open access article under the CC BY license (http://creativecommons. org/licenses/by/4. 0/) DOI: http://dx.doi.org/10.22159/ajpcr.2019.v12i1.28479

\section{INTRODUCTION}

Inflammation is the reaction in living tissues caused due to injury, infection, or irritation which causes a complex array of enzyme activation or mediator release or fluid extravasations, cell migration, tissues breakdown, and repair, which are aimed to host defense and mostly activated in disease condition. Inflammation releases the lysosomal enzyme which produces a variety of disorders, leading to the tissue injury by damaging the macromolecule and lipid peroxidation of membrane [1,2]. The mechanism of inflammation is attributed in part to release of reactive oxygen species (ROS) from activated neutrophils and macrophages. Free radicals are important mediators that prove or sustain inflammatory process, and radical scavengers can attenuate the inflammation [3]. In addition, ROS propagate inflammation by stimulating the release of cytokines such as interleukins-1 (ILs-1), tumor necrosis factor- $\alpha$ (TNF- $\alpha$ ), and interferon- $\gamma$, which stimulate recruitment of additional neutrophils and macrophages [4]. Prolonged inflammation leads to rheumatoid arthritis, hay fever, and atherosclerosis and also the development of infectious disease such as leprosy, tuberculosis, syphilis, asthma, inflammatory bowel disease, and autoimmune disease [5]. Rheumatoid arthritis is a chronic inflammatory disease of joints that result in joint pain swelling and destruction. It affects an estimated $1 \%$ of adult population throughout the world [7]. It is an autoimmune disorder characterized by synovial proliferation, inflammation, and subsequent destruction such as deformity of joints or destruction of cartilage and bone [6]. The various mediators involved in the process include receptor activator of $\mathrm{NF}_{\mathrm{K}} \mathrm{B}$ (RANK) ligand and its receptor RANK, pro-inflammatory cytokines, for example, TNF- $\alpha$, IL1, IL-6, IL-17, and IL-18 and matrix-degrading enzyme, for example, matrix metalloproteases and cathepsin $\mathrm{K}$ [9]. The pathophysiology of exaggerated synovial tissues involves hyperplasia and subintimal infiltration of $\mathrm{T}$ and $\mathrm{B}$ lymphocyte; this results in pannus tissues that irreversibly destroy the cartilage and bone in the affected joints. Polymorphonuclear leukocytes and macrophages are also stimulated which result in the production of inflammatory mediators including large amount of superoxide and hydrogen peroxide that can cause significant impairment and destruction of synovial fluid, cartilage, and other articular constituents [8].

As of now, there are four sorts of medication recommended for the treatment of rheumatoid joint pain which are Non-steroidal antiinflammatory drugs (NSAIDs) e.g.: diclofenac, ibuprofen., Steroidal hormones e.g. prednisone, dexamethasone. Disease modifying antirheumatic drugs (DMARDs) e.g.: methotrexate, hydroxychloroquine, immunosuppressant (e.g.: azathioprine, cyclosporine) [10].

Parmelia perlata (Huds.) Ach. is a perennial lichen species belonging to family Parmeliaceae. They are found on the rocks or dead wood and also cultivated in temperate Himalayas and Kashmir hills. They are commonly known as Patthar phool, Kalpashee, Chhadila, Stone flower, Dagad phool, and Charela [11]. In traditional medicine, it was used for the treatment of edema, arthritis, for counteracting poisons, toxicosis, fever, obesity, eczema, cardiac tonic, refrigerant, and gout. The folklore claim states it to have the activity for the treatment of dyspepsia, diarrhea, dysentery, antiulcer, spermatorrhea, amenorrhea, astringent, diuretic, and also in promoting wound healing $[12,13]$. The early investigation resulted in the isolation of various chemicals such as parmelanostene, parmelabdone, tridecylmyristate, 3-ketooleanane, icosan-1-ol, and usnic acid. $[14,15]$. It has been reported to possess antioxidant, hypolipidemic and cytotoxic potential [16], antibacterial [17], hepatoprotective [18], antimicrobial [19,20], antidiabetic [21], antiulcer [22], and antiviral activity [23]. The objective of the study was to establish the potential of P. perlata for the anti-inflammatory and antiarthritic activity.

\section{METHODS}

The lichens species of $P$. perlata was collected from local herbal market in Chennai. It was authenticated by Professor P Jayaraman of Plant Anatomy Research Centre (PARC), Herbal PARC unit, 
Tambaram, Chennai. The authentication number on the certificate is PARC/2016/3228.

\section{Extraction}

The dried P. perlata was coarsely grounded and was defatted using petroleum ether and successive extraction was done using $70 \%$ alcohol by maceration process for $72 \mathrm{~h}$ at room temperature with intermittent shaking. The extract was concentrated under reduced pressure and concentrated. The extract was kept in air-tight container and stored in cool temperature $[24,25]$.

\section{Preliminary phytochemical analysis}

A small quantity of the powdered lichen was subjected to phytochemical tests using established chemical procedure. Standard procedures for the determination of alkaloids, tannins, saponins, glycosides, flavonoids, carbohydrates, fats and oil was performed and reported.

\section{THE IN VITRO ANTI-INFLAMMATORY ACTIVITY}

\section{Human RBC membrane stabilization method}

The in vitro anti-inflammatory activity of hydroalcoholic extract of $P$. perlata (HAEPP) extract of P. perlata was evaluated by human red blood cell membrane stabilization method. The blood was collected from healthy human volunteer who had not taken any NSAIDS for 2 weeks before the experiment, and the blood was mixed with equal volume of Alsever solution (2\% dextrose, $0.8 \%$ sodium citrate, $0.5 \%$ citric acid, and $0.42 \% \mathrm{NaCl}$ ) and centrifuged at $3000 \mathrm{rpm}$. The packed cells were washed with isosaline and a $10 \%$ suspension was made. Various concentrations of extracts were prepared, namely 50, 100, 250, 500 , and $1000 \mathrm{mcg} / \mathrm{ml}$ using distilled water and to each concentration of $1 \mathrm{ml}$ of phosphate buffer, $2 \mathrm{ml}$ hyposaline, and $0.5 \mathrm{ml}$ of human red blood cells (HRBC) suspension were added. It is incubated at $37^{\circ} \mathrm{C}$ for $30 \mathrm{~min}$ and centrifuged at $3000 \mathrm{rpm}$ for $20 \mathrm{~min}$. The hemoglobin content of the supernatant solution was estimated using UV-visible spectrophotometer at $560 \mathrm{~nm}$. The diclofenac sodium was used as standard.

\section{THE IN VITRO ANTIARTHRITIC ACTIVITY}

\section{Egg albumin denaturation method}

The reaction mixture $(5 \mathrm{~mL}$ ) consisted of $0.2 \mathrm{~mL}$ of egg albumin (from fresh hen's egg), $2.8 \mathrm{ml}$ of phosphate-buffered saline (PBS, pH6.4), and $2 \mathrm{ml}$ of varying concentrations $(50,100,250,500$, and $1000 \mu \mathrm{g} / \mathrm{ml})$ of drug. A similar volume of double-distilled water served as the control. Next, the mixtures were incubated at $37^{\circ} \mathrm{C} \pm 2^{\circ} \mathrm{C}$ in a BOD incubator for $15 \mathrm{~min}$ and then heated at $70^{\circ} \mathrm{C}$ for $5 \mathrm{~min}$. After cooling, the absorbance was measured at $660 \mathrm{~nm}$ using the vehicle as a blank. Diclofenac sodium in the concentrations of $50,100,250,500$, and $1000 \mu \mathrm{g} / \mathrm{mL}$ was used as the reference drug and treated similarly for the determination of absorbance.

The percentage inhibition of protein denaturation was calculated using the following formula:

$\%$ inhibition $=100 \times[\mathrm{Vt} / \mathrm{VC}-1]$

Where,

$\mathrm{Vt}=\mathrm{Absorb} a n c e$ of the test sample,

$\mathrm{Vc}=$ Absorbance of control.

\section{Statistical analysis}

All data were presented as the mean \pm standard deviation. Statistical analysis was performed by one-way analysis of variance to evaluate significant differences between groups using GraphPad Prism 5 (GraphPad Software Inc., La Jolla, CA, USA). p $<0.05$ was considered statistically significant.

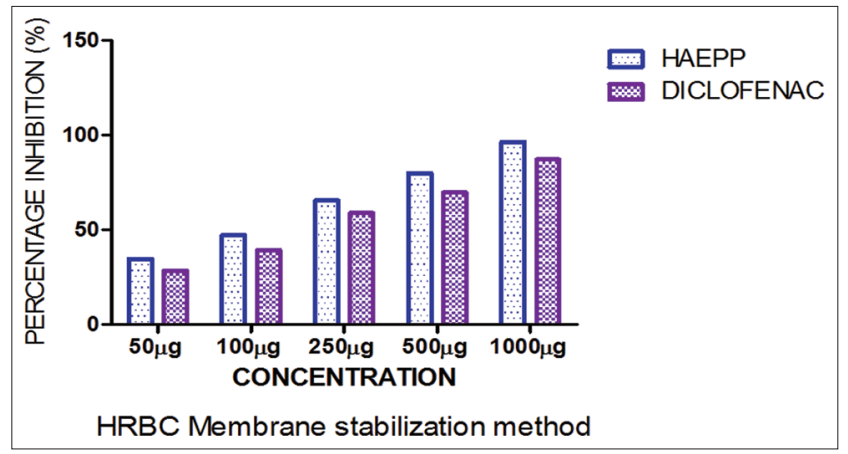

Fig. 1: Anti-inflammatory activity using HRBC membrane stabilisation method

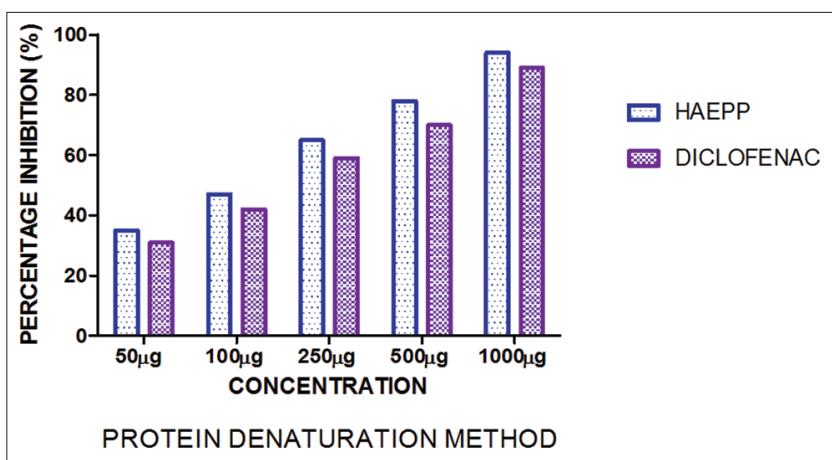

Fig. 2: Anti-arthritic activity using egg protein denaturation method

\section{RESULTS}

\section{HRBC membrane stabilization method}

The HAEPP showed anti-inflammatory activity (Fig. 1) by inhibiting the hemolysis of HRBC. The HEAPP and diclofenac response were on dose concentration as preparation showed the increase in activity as the concentration of the solution increased from $50 \mu \mathrm{g}$ to $1000 \mu \mathrm{g} / \mathrm{ml}$. The minimum activity was seen at $50 \mu \mathrm{g}$ as $34.6 \%$ and $30.87 \%$, respectively, and as the dose was increased to $100 \mu \mathrm{g}$, the activity was $47.33 \%$. The $250 \mu \mathrm{g}$ concentration showed the activity as $65.22 \%$ and the $500 \mu \mathrm{g}$ concentration had $79.86 \%$ response. The maximum activity was seen at $1000 \mu \mathrm{g}$ as it inhibited the $96.25 \%$ and 87.70 , respectively, of the hemolysis

\section{Egg protein denaturation method}

The HAEPP showed antiarthritic (Fig. 2) activity by inhibiting the protein denaturation. The minimum activity was seen as $35.14 \%$ at $50 \mu \mathrm{g}$ concentration for HAEPP and $31.68 \%$ for diclofenac. At $100 \mu \mathrm{g}$ concentration, the response was seen as $47.58 \%$, and at $250 \mu \mathrm{g}$ concentration, the response was $67.25 \% .78 .14 \%$ activity was seen at $500 \mu \mathrm{g}$ concentration. The maximum activity for $1000 \mu \mathrm{g}$ was seen as $94.20 \%$ and $89.66 \%$, respectively, for both HAEPP and diclofenac.

\section{DISCUSSION}

The in vitro anti-inflammatory activity has been studied using the HRBC membrane stabilization method as the erythrocyte membrane and lysosomal membrane are analogous and stabilization of erythrocyte implies that the HAEPP extract may well stabilize lysosomal membranes as it is important in limiting the inflammatory response by preventing the release of lysosomal constituents of activated neutrophil, such as proteases and bacterial enzymes, which further causes inflammation of tissues and damage on extracellular release. The extracellular activity of these enzymes is noted to be associated with acute or chronic inflammation. The nonsteroidal drugs act either by inhibiting these 
lysosomal enzymes or by stabilizing the lysosomal membrane [26].

Rheumatoid arthritis is the most common of autoimmune diseases which is prominently manifested by the inflammation and joint pain. There has been large number of mortality and morbidity associated with RA and thereby it has left substantial socioeconomic impact. The currently synthetic drugs are mainly used for symptomatic relief and side effect associated [27].

Thus, it has become essential to find an alternative method for the treatment of arthritis, thus resulting in the use of CAM therapies for the treatment of arthritis. The current researches are focused on the identification and isolation of active principle(s) from crude extracts of known medicinal plants/herbs, it's to be overlooked that the strong synergism of several constituents in the crude drug may prove more potent and effective than any single purified compound, and this may also help to nullify the toxic effects of individual constituents [28].

\section{CONCLUSION}

The $P$. perlata, a potent unexplored lichen species, claimed to have an anti-inflammatory activity showed the significant response using in vitro model of HRBC membrane stabilization method for anti-inflammatory activity. The response increased gradually as the dose potentiated. The antiarthritic activity was also studied based on the results of the inflammatory action because the prolonged phase of inflammation leads to arthritis in bones and tendons. The antiarthritic activity was also eminent in the protein denaturation method. Thus, stating HEAPP has a potent anti-inflammatory activity and antiarthritic activity. A further study has to be conducted to establish the pharmacological evidence behind the compound and the mechanism of action of the HAEPP on the inhibition of inflammation process.

\section{ACKNOWLEDGMENT}

The authors are grateful to the Dean of SRM College of Pharmacy, SRM Institute of Science and Technology, for her continued support. They also thank the Vice Principal and Head of the Department of Pharmacology, SRM College of Pharmacy, SRM Institute of Science and Technology, for her continued guidance and moral support for the research work. The authors also thank their fellow postgraduate research scholars for their timely help and support in execution of the project activities.

\section{AUTHORS' CONTRIBUTION}

Dr. Chitra V - Guide. Yogesh Diwakar - Performed the studies. Evelyn Sharon S - Helped in performing the statistical analysis.

\section{CONFLICTS OF INTEREST}

The authors whose name listed below certify that we have no conflicts of interest.

\section{REFERENCES}

1. Kumari CS, Yasmin N, Hussain MN, Babuselvam M. In vitro antiinflammatory and anti- arthritic property of rhizopora. Int J Pharm Sci Res 2015;6:3.

2. Pant K, Kshitij A, Prem S. To study in vitro anti-inflammatory activity of Anthracephalus cadamba leaves extract. DHR Int J Pharm Sci 2012;3:55-60

3. Arya D, Meena M, Neha G, Vidya P. In vitro anti-inflammatory and anti-arthritic activity in methanolic extract of Cocculus hirsutus (L.) Diels. In vivo and In vitro. Int J Pharm Sci Res 2014;5:1957-62.

4. Conforti F, Sosa S, Marrelli M, Menichini F, Statti GA, Uzunov D, et al. In vivo anti-inflammatory and in vitro antioxidant activities of Mediterranean dietary plants. J Ethnopharmacol 2008;116:144-51.
5. Rahman H, Eswaraiah MC, Dutta AM. In-vitro anti-inflammatory and anti-arthritic activity of Oryza sativa Var. Joha rice (An Aromatic Indigenous Rice of Assam). Am-Euras J Agric Environ Sci 2015;15:115-21.

6. Pavithra TK, Smitha KP, Kulashekar KS, Kumar BS. Evaluation of in vitro anti-arthritic activity of Vitex negundo against the denaturation of protein. Int J Curr Microbiol App Sci 2015;4:87-90.

7. Geetha DH, Jayashree I, Rajeswari M. In vitro anti-arthritic activity of Elaeocarpus serratus Linn. (Elaeocarpaceae). Int J Pharm Sci Res (IJPSR) 2015;6:2649-51.

8. Jayanthi MK, Naidu SV, Sunil P. Antioxidant and anti-arthritic activity of allicin in animal models. Int J Pharm Sci Res IJPSR 2015;6:1150-5.

9. Vennila V, Anitha R. In vitro evaluation of anti-arthritic activity in different solvent extracts from Cuscuta reflexa. World J Pharm Pharm Sci 2015;4:1340-50.

10. Mondal P, Das S, Mahato K, Borah S, Junejo JA, Zaman K. Evaluation of anti arthritic potential of the hydro-alcoholic extract of the stem bark of Plumeria rubra in freund's complete adjuvant induced arthritis in rats. Int J Pharm Sci Res IJPSR 2016;7:3675-88.

11. Ministry for Health and Family Welfare. The Ayurvedic Pharmacopoeia of India. New Delhi: Ministry for Health and Family Welfare; 2010. p. 171

12. Khare CP. Indian Herbal Remedies? Rational Western Therapy, Ayurvedic, and other Traditional Usage, Botany. New Delhi: Springer; 2004. P. 352-3.

13. Khare CP. Indian Medicinal Plants. New Delhi: Springer; 2007. p. 464.

14. Abdullah ST., Hamid H., Ali M., Ansari SH., Alam MS. Two new terpenes from the lichen Parmelia perlata. Indian J Chem - Sect B Org Med Chem 2007;46:173-6.

15. Verma SK. Pharmacological and phytochemical aspects of lichen Parmelia perlata: A review. Int J Res Ayurveda Pharm 2016;7 Suppl 1:16-8.

16. Rahman H, Vijaya B, Ghosh S, Pant G, Sibi G. In vitro studies on antioxidant, hypolipidemic and cytotoxic potential of Parmelia perlata. Am J Life Sci 2014;2:7-10.

17. Vidyalakshmi A, Kruthika K. Antibacterial activity of Parmelia perlata. Asian Pac J Trop Biomed 2012;2012:892-4.

18. Shailajan S, Joshi M, Tiwari B. Hepatoprotective activity of Parmelia perlata (Huds.) Ach. Against ccl4 induced liver toxicity in albino wistar rats. J Appl Pharm Sci 2014;4:70-4.

19. Rauf A, Latif A, Rehman S, Afaq SH. Study on extracts of Parmelia perlata Ach. For its antimicrobial potential against certain microorganisms. Int Res J Pharm 2013;4:102-6.

20. Hussain M, Raza SM, Farooq U, Bakhsh H, Majeed A, Aziz A. In vitro antimicrobial potential of lichen (Parmelia perlata) against different pathogenic microbes. Int J Pharm Sci 2014;4:666-70.

21. Jothi G, Brindha P. Antidiabetic and antihyperlipidemic effect of Parmelia perlata. Ach. In alloxan induced diabetic rats. Int J Pharm Pharm Sci 2014;6:43-6.

22. Gehlot V, Mahant S, Vijayraghwan P, Das K, Hoda S, Das R. Therapeutic potential of lichen Parmelia perlata against dual drug-resistant helicobacter pylori isolates. Int J Pharm Pharm Sci 2016;8:205-8.

23. Esimone CO, Ofokansi KC, Adikwu MU, Ibezim EC, Abonyi DO, Odaibo $\mathrm{GN}$, et al. In vitro evaluation of the antiviral activity of extracts from the lichen Parmelia perlata (L.) ach. Against three RNA viruses. J Infect Dev Ctries 2007;1:315-20.

24. Sumanya H, Lavanya R, Reddy CU. Evaluation of in vitro anti-oxidant and anti-arthritic activity of methanolic extract of marine green algae Caulerpa racemosa. Int J Pharm Pharm Sci 2015;7:340-3.

25. Monika M, Kantaporn J, Rinrampai P, Frank M, Helmut V, Siriporn O. Anti-inflammatory, antibacterial, and antioxidant activities of Thai medicinal plants. Int J Pharm Pharm Sci 2015;7:123-8.

26. Suganya G, Kumar PS, Dheeba B, Sivakumar R. In vitro antidiabetic, antioxidant and anti-inflammatory activity of Clitoria ternatea L. Int J Pharm Pharm Sci 2014;6:342-7.

27. Sutar NG, Pal SC. Evalution of antiarthritic activity of leaf extracts of Pergularia daemia [Forsk] plant in experimental animals. Int J Pharm Pharm Sci 2014;6:198-200

28. Paul S, Das AP, Bhattacharjee S. Rheumatoid arthritis: Molecular basis and cures from nature. Int J Pharm Pharm Sci 2015;7:30-9. 